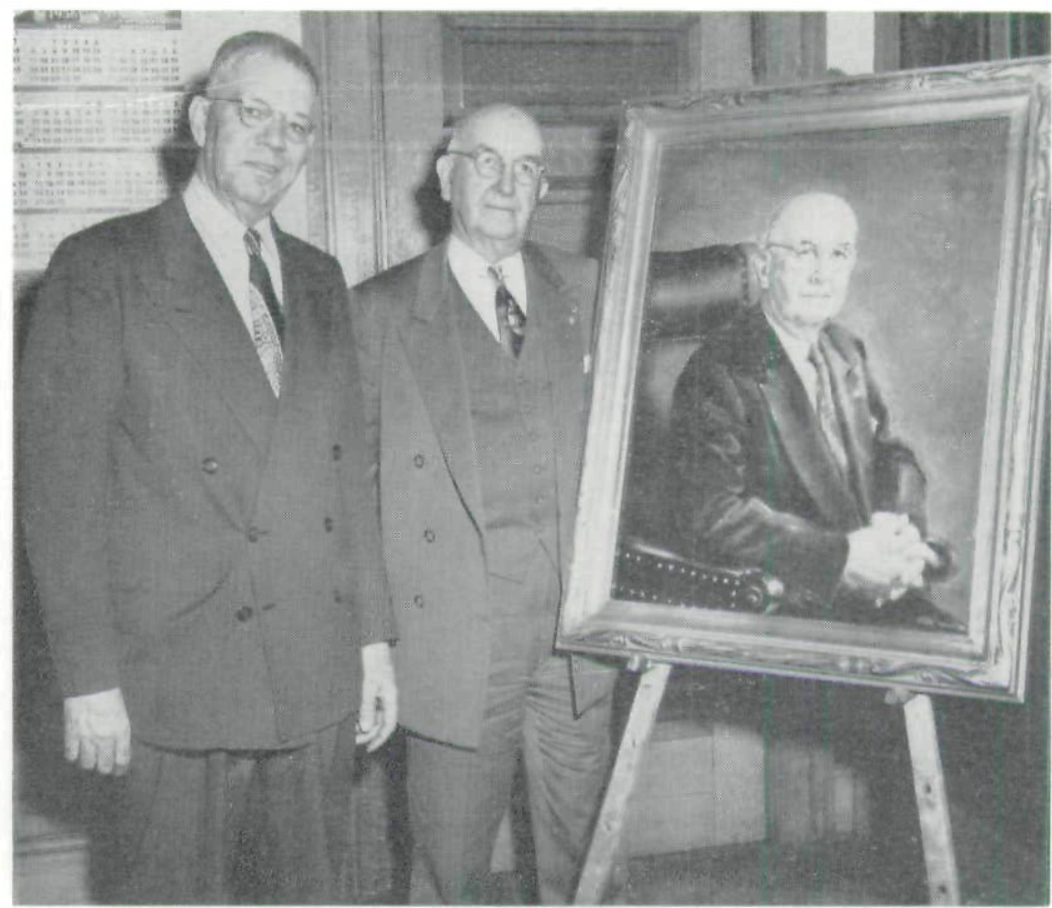

Curator Cook Receiving Portrait of Senator McFarlane

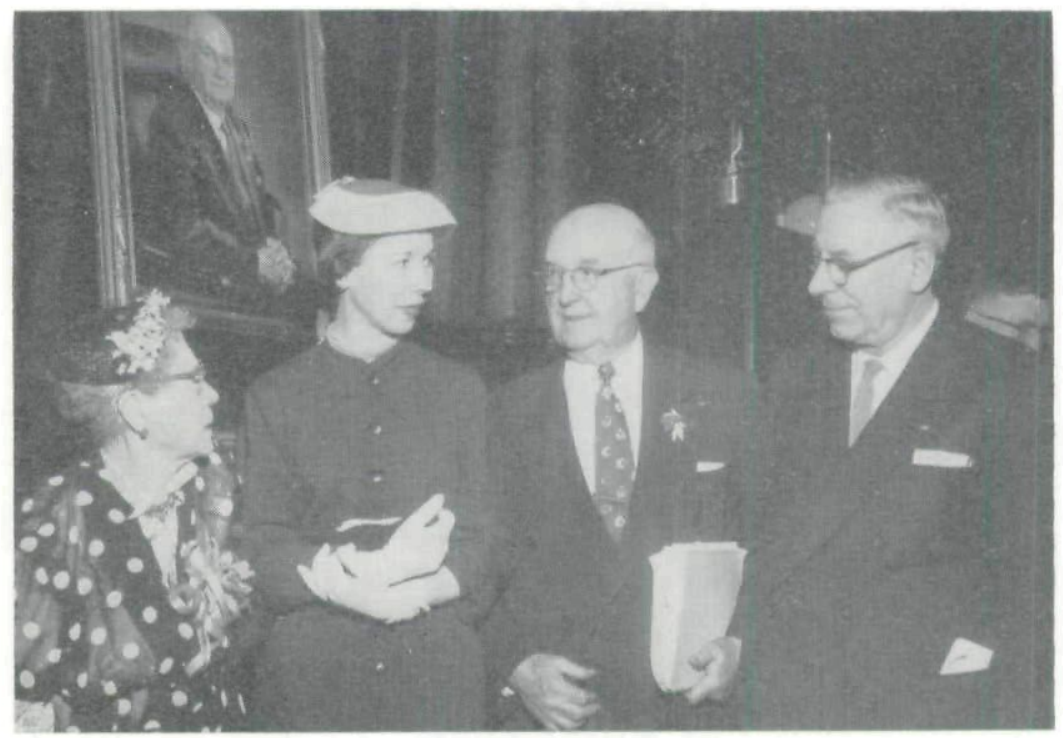

Mrs. McFarlane, Mrs. Kent, artist, Sen. McFarlane, Judge Davidson 


\title{
Iowa Honors McFarlane's Long Legislative Service
}

\author{
By Walter H. Beam
}

Upon the walls of the spacious galleries of the State Historical building at Des Moines, are displayed portraits in oil of countless Iowa men and women of distinction. Here are the great and the renown of Hawkeyedom-statesmen, soldiers, admirals, clergymen, authors, sages, scientists and Iowans of attainment in wide fields of action in the state and nation.

And now, to these has been added another worthy of honor-the Dean of the Iowa legislature-a man who has served Iowa with marked ability almost continually in that body over a period of 42 years, and during the time, since 1915 to the present, still a senator, has been either a member of the house or the senate or lieutenant governor, presiding over two senates in the last mentioned capacity, and also as speaker over two houses. At one session he served as presiding officer of the senate and a member of the house the same day.

Under the sponsorship of the Pioneer Lawmakers Association of Iowa, the wide circle of friends of Senator Arch W. McFarlane of Waterloo, whose service as lieutenant governor was from 1929 to 1933, gathered in the house chamber of the capitol April 17, and presented to the State Department of History and Archives a splendid life-sized oil portrait of the senator, painted by Mrs. James Kent of Iowa City.

Judge Harold E. Davidson of Clarinda, vice-president of the Pioneer Lawmakers, called the meeting to order and presented B. F. Swisher of Waterloo, 52 years a lawyer there, to preside during the ceremonies. $\mathrm{He}$ introduced Mrs. Kent, the painter of the portrait.

First upon the formal program was Capt. H. T. Wagner, Black Hawk county sheriff for 36 years, who told of the many elections in Black Hawk county in which 
his friend and he often had campaigned together; and commented upon the senator's high character and integrity, his standing as a citizen and businessman and the delight of citizens of the county in McFarlane's availability and ability as a legislator. In part $\mathrm{Mr}$. Wagner, the dean of Iowa sheriffs, said:

An opportunity to pay tribute to one whose friendship is of fifty years standing, is truly something for which to be thankful. The limited time assigned me today is far too short to say all the things I would like to, or that could be said in extolling his virtues. Arch's achievements as a legislator are a matter of record, but there are some details that only research will reveal.

\section{The Distinguished Record}

He is the only person who has presided twice over both house and senate and served as member of each.

$\mathrm{He}$ has served more sessions than any other person-a total of twenty-three regular and special sessions.

$\mathrm{He}$ is the only person who ever presided over the house in two regular and one special session.

$\mathrm{He}$ is the only person who served in both the house and senate the same day.

$\mathrm{He}$ is the only person who ever has served as speaker pro tem, speaker and majority floor leader of the House of Representatives.

He is on record as shown in the house and senate journals more times than any other person, living or dead.

In his own home town, he is known by all to be a product of a fine Christian home, which is reflected in his daily life, his business and in the halls of our legislature. By reason of his honesty, integrity and courage to defend his convictions, he commands respect by all who know him.

His loyalty to his country, his service to his church and the affection for his wife, Elsie, are without parallel.

In making an appraisal of an individual, I look for the things done while not under observation, but with unquestioned sincerity of purpose and also without publicity. The true nature of such an individual will assert itself when administering kindness to those in distress, and without solicitation, providing the necessities of life for the unfortunate and making comfortable the home that has been chilled by winter's blasts. In these things I know he has found much satisfaction. I know about them not from him, but from the many recipients of his generosity.

Another trait rightly ascribed to him, is an affable and friendly manner; the kind that radiates sunshine and makes every- 
one at ease when in his presence and one who is missed when he departs. It is men like Arch who inspire confidence of the people, and to whom they look for counsel and honest government. It is men like him whose record will be history in the annals of Iowa as an example and a pattern for posterity. We, of Black Hawk county, are proud of him as a citizen, a legislator and statesman, and can subscribe to all the fine things that will be said of him on this occasion.

\section{Tribute From Former Offictal}

Warren Wells of Council Bluffs, former legislator and former chairman of the State Tax commission was next introduced and termed the occasion an "extraordinary ceremony of congratulation on a remarkable record." He said in part:

On this day, you are engaged in the conduct of an extraordinary ceremony, the purpose of which is to celebrate the legislative accomplishments of one of your own members, the Hon. Arch W. McFarlane, whose record of legislative service stands unsurpassed in both duration and in quality.

Many of us who sit here with Arch in his hour of acclaim have actually witnessed the building of his unparalleled legislative career-all Iowa is of one voice and one mind in tendering meaningful congratulations to the splendid gentleman in whose honor we are met. The account of his attainments as set out in the historical annals of Iowa has now become permanent record so that posterity may continue to pay homage to a truly great legislator.

What qualities do I, as an average man, look for in my legislator? I want my legislator to be alert, studious and personable; I want him to be a student of legislative procedure, untiringly industrious and a good listener. These qualities, if possessed in good measure, will draw and will command the attention of his fellow legislators; will enhance their estimate of his competency; and will promote his effectiveness in the serious business of law-making. These qualities are desirable, very desirable.

But, I want still more of my legislator-what I now demand are qualities that are not only desirable, they are essential, they are indispensable. I want my legislator to be an honest man. Any embellishment of that term is superfluous, but the absence of honesty in a legislator constitutes a formidable barrier to a wholesome relationship with his fellow assemblymen and will nullify the possibility of any worthwhile legislative accomplishment on his part. 


\section{Character A Basic Quality}

In an address made in this city, some sixty days ago, a courageous gentleman, high in the councils of our national government, made use of these words: "Character is the one thing you make in this world that you take with you into the next," and then for good measure, he added: "Principle is important too, because it's the foundation upon which character is built. Character and honesty are inseparable."

What further indispensable quality do I look for in my legislator? I want him to be committed unreservedly, not alone to the interests of the people of his legislative district, but with equal fervor to the interests of all the people of the entire state.

If he measures up to this commitment, he will do these things:

(1) He will be ever mindful of the fact that the state he is attempting to serve is the creature of its people. People are the architects of all free governments.

(2) He will support measures that provide for proper maintenance and prudent development of all our state institutions -that's an obligation.

(3) He will give considerate attention to the legislative problems of all segments of our society-that's representative government in action.

(4) He will zealously protect the fiscal solidarity of our state's economy by adjusting judiciously our state expenditures to the available state revenue that our people can afford to pay. That's sound business sense.

We are here to honor a man who has done exceptional things for us and for posterity. In my search for the basic reasons that made possible his 42 years of legislative service, I deemed it pertinent to examine the fundamental responsibilities of a legislator and also the qualities that the average man looks for in determining his fitness.

The extent of the senator's participation in crucial or highly controversial lawmaking is well-known to his associates and friends, and the full accounts of his legislative activity and how well he discharged the fundamental responsibilities of a legislator are spread through 44 years of published record in the house and senate journals. It's a constructive record.

In a republic such as ours, an enlightened electorate makes wise decisions. It follows that the endorsement of the senator's legislative conduct, in elections too numerous to count, is mute but convincing evidence that the folks at home found in the person of the "Gentleman from Black Hawk" all the desirable and essential qualities that the average man looks for. 
Governor Leo Hoegh was listed upon the program, but on account of illness could not appear, and his secretary, Paul Parker, spoke briefly for the executive, paying tribute to the honored guest.

\section{UnVeiring of the Painting}

The painting upon an easel near the chairman was unveiled by Mrs. Leo Hoegh with a few appropriate words, and former congressman, Burton E. Sweet, of Waverly, a warm personal friend of Senator McFarlane, of long standing, and also former president of the Pioneer Lawmakers Association, made the presentation address. To him McFarlane's long and effective legislative service was an example of individual fitness seldom rivaled for participation in the state's legislative affairs, and having a thorough knowledge of parliamentary procedure and law, the basis that underlies all governmental action by states and free nations.

Mr. Sweet spoke with emphasis, saying:

I became acquainted with Arch W. McFarlane in 1914, when he was a candidate for the Iowa House of Representatives from Black Hawk county and I was a candidate for congress from the old Third Iowa district, known as the Allison and Henderson district, and sometimes facetiously referred to as the "Monkey-Wrench" district.

Thus began a friendship that has lasted for forty-two years, unbroken and undimmed. "Friendship is that gentle salutation of the heart that lives in all the languages of men. It is a little less than love-a little more than comradeshipand winds and turns its way through all our acts and deeds and dreams, through song and toil and battlefield."

Mr. McFarlane continued as a representative in the lower house of the Iowa legislature and in the Thirty-eighth, the Thirty-eighth extra and the Thirty-ninth General Assemblies of Iowa he was elected speaker and presided over the house at those sessions. He made a very fine speaker, an impartial speaker; he treated friend and foe alike in all his decisions.

He was elected to the state senate in 1926 . He was elected lieutenant governor of Iowa in 1928, and as lieutenant governor he was the presiding officer of the state senate, and presided over the senate with the same impartiality' that he had presided over the house. He has been in the Iowa legislature for about forty-two years. He is now a member of the state senate, and will continue as a senator for another two years. 
Parliamentary law has played a great part in the drama of events for the last two thousand years. In fact, it played an important part in the world's history during the Christian. Era-it is a concomitant of the Christian Era. Its origin was in the ups and downs of the Grecian government, the Roman government, and we next find it coming to light in England in the House of Commons. Parliamentary law is largely the law of custom and precedent. It has had a fine example in the House of Commons in England. In fact, England has no written constitution, and all its proceedings in the House of Commons are according to parliamentary law.

In this country, after we gained our independence, we formed our Constitution and that, too, was the result of customs that had sprung up in the colonies. As a result, we have one of the greatest Constitutions that the world has ever known. In fact, Premier Gladstone of England once said that it was the greatest organization of government, the beginning of a government, that was ever produced by the brain of man.

As a result, we have the American congress-the House of Representatives and the United States Senate-the greatest deliberative body in the world. All proceedings in each of these houses are according to parliamentary law, and have been dominated by great speakers and great presidents. Let me name a few of the speakers, Henry Clay, James G. Blaine of Maine, Thomas B. Reed of Maine, Uncle Joe Cannon of Illinois, David B. Henderson of Iowa, Champ Clark of Missouri, Sam Rayburn of Texas, our present speaker. All have dominated the affairs of this government under parliamentary procedure and parliamentary proceedings of the two houses are largely founded upon precedent and custom. These great men dominated the legislative history of this country and have performed their duties so well that we have followed out the concepts and proceedings handed down to us by our forefathers. We have formed the United Nations, and their proceedings are dominated by parliamentary procedure, in our endeavors to gain the Peace of the World.

"When the war drums throb no longer, and the battle flags are furled, in the parliaments of men, in the Federation of the world ..." "Through the ages one increasing purpose runs, and the thoughts of men are widening with the progress of the suns."

In the state of Iowa, the proceedings of both houses of the legislature are dominated by parliamentary law. We have had some great speakers. Let me name a few of themWillard Eaton of Osage, Mitchell county, Nate Kendall of Monroe county, George Clarke of Dallas county, Robert Blue of Wright county, William I. Atkinson of Butler county, Arch 
W. McFarlane of Black Hawk county, Henry Burma of Butler county, William S. Lynes of Bremer county. All have been great speakers, and have dominated legislation and have given us the standing that we now have as a state.

I am not saying to you today that Arch W. McFarlane is the greatest speaker we have ever had, but I am saying to you that he is a man of great integrity, great common sense and is a prince of a parliamentarian-a leader of men.

I am saying to you that on account of his long service in the legislature of Iowa, there is no important bill that has passed without receiving the imprint of his penetrating mind and the stamp of his legislative genius. $\mathrm{He}$ has performed a great service to a large constituency in Black Hawk county that has kept him in the limelight in the legislature for the last forty-two years. Above all, he is an outstanding American citizen.

There has been painted a portrait by a competent artist, Mrs. James Kent. She has portrayed upon the breathing canvas, his likeness, his form and features, and we have met here today to do honor to him for the great service that he has rendered the state in a legislative capacity. $\mathrm{He}$ is as prominently known as any governor or United States senator by the people of Iowa.

In behalf of the Pioneer Lawmakers Association, I now turn over to the Department this portrait, where it will remain in the archives for passersby to see and that coming generations may know that there was such a man as Hon. Arch W. McFarlane, at present a member of the Iowa state senate.

\section{Acceptance By Curator Cook}

In acceptance of the portrait to be hung in the Iowa State Department of History and Archives, Curator Claude R. Cook said:

When I was about 17 years old, the superintendent of schools, who incidentally, while much older than I, was a product of our own community, had the impression that there might be some latent talent in my make-up for oratory. He induced me to commit and do a reading for one of the school's exercises which was entitled "Bill." (The reading I am not going to recite to you so don't be alarmed or frightened, I'll just tell you the story of it).

The story concerned a gentleman whose son Bill had been gone from home a number of years and had made his own way. He went to the post office one morning, as we all used to do in the smaller towns, to get his mail. There was a letter from his son and the father was very disturbed. He read the letter and was certain that Bill was 
in serious trouble. He did not know how to tell his wife, so he went by their minister's house and asked him if he would go and break the news to the boy's mother. After some questioning, the minister learned that the letter was to Bill's father and the last line of the reading was, "Bill's in the legislature but he don't say what fer."

I have known Arch McFarlane for 35 years. In 1921, when he was speaker of the house I came to Des Moines to do the chaplain's work by opening the house with prayer. I remember that Senator Kimberley picked me up at the Savery hotel and brought me to the state house, and took me to the cloak room. I was at the age where I knew a great many things that I hadn't learned yet, and when the porter reached out for my hat, I thought he was wanting to shake hands with me, so I shook hands with him. When he took me to the front of the house, and introduced me to Arch McFarlane and told him why I was there, Arch told me, "Look the House over, Cook, and pray for the state."

A political career is a distinguished one. I know there are a great many people who think that being interested in politics or even being in politics is something to be shunned. But they are either ignorant of or ignoring their history of our government which is a government of party. Those who shun it and refuse to participate in it are denying themselves the opportunity which the foundations of our government created for them in the first place. Everybody should be interested and it is extremely fortunate that we have men of the caliber of Arch McFarlane who will permit their services to be used by their constituency.

There has never been any question about why Arch McFarlane was in the legislature, because of his long record of achievement. It stands for itself, a remarkable record of 42 years of service, longer than any other man has ever served in the Iowa legislature. $\mathrm{He}$ has the distinction of having been elected to every state office to which he ever aspired. Unless there may be some question here, let me say he never was a candidate for governor. He has been lieutenant governor, speaker of the house, member of the house and now member of the senate. It is a remarkable record and there is a vast amount of legislation for which he was either responsible or had a part in bringing about.

A remarkable thing about Arch is that he has kept pace with the times and that he has progressed along with the age in which he was serving. This scientific age in which we are living is moving us at a rapid rate. We do not all know where we are going and the future is so much likely to surpass any of the achievements of the past that undoubtedly 
there can be very little comparison. Not too long ago Mr. Charles Dayton, deputy treasurer, asked me if I thought the next 50 years would show as much advancement as the last $50 \mathrm{had}$, and I told him that I thought the next 50 years would make the last 50 look like we might have been standing still.

It is an honor for us here today to honor such a distinguished career as Arch McFarlane has had and this magnificent portrait of Arch, which has been painted by a lovely lady, (I am sure she is a lovely lady although I haven't met her yet, for such a fine painting could only be produced by a lovely lady) is a distinguishing recognition of the service Arch McFarlane has given the state through his legislative activities. Of course, I am here to accept the painting, I am going to accept it, you understand, (I had to agree to accept it before Arch would let me appear on this program) and we will place it in the portrait section of the Iowa State Department of History and Archives, Historical Building. I was about to say we would hang Arch, but I would rather use the word "place" under the circumstances.

On behalf of the state and the Iowa Department of History and Archives, of which he is the curator and director, Claude R. Cook accepted the painting for installation on the walls of the State Historical building.

\section{SENator McFarlane Responds}

Standing not too far from his portrait, McFarlane was met with a flood of applause when presented by Chairman Swisher. So true is the likeness that either the senator or the portrait could have begun to talk without surprise to the appreciative audience. He spoke humbly, saying:

It is a great honor for any Iowan to gain admission to the magnificent gallery of distinguished citizens whose portraits grace the walls of the Iowa historical building. I feel rather abashed at the distinction given to me. It is fitting though, that the state of Iowa should preserve, for future generations, the likenesses of the men who have contributed greatly in their day, to the creation and the history of their state.

I should prefer that my portrayal be considered simply as representative of the rank and file of Iowa citizens, who, in relatively humble capacities, have served their state well.

The history of Iowa is not a record of geography, of wars, of battles, of plenty, nor famine. It is made up of the lives of the men and women who have lived in it. I would be the last to attempt to rank myself among our great states- 
men and soldiers. It has been my good fortune during the long period of public service, to have known personally many of Iowa's great men. It has also been my fortune to have participated as a legislator and as lieutenant governor in the lawmaking of this state during an extremely vital period of its existence.

As a youth, I did not realize that the men and women whom I knew as a boy, represented a generation which founded our state. They were the pioneers. I remember well their great interest in the Memorial Day services, the fife and drum corps, the addresses by prominent veterans of the Civil war. As a young student in school, wearing short trousers, I delivered Lincoln's Gettysburg address before a large and enthusiastic crowd in Brown's old opera house in Waterloo. I shall always remember that occasion, and the men who were then young as we measure life times today, and all of whom have passed to their reward.

I can best explain my feeling for these pioneers, who worked so diligently without fear of criticism, by referring to a motto upon the desk of Gen. Douglas McArthur which is an excerpt of a speech by Abraham Lincoln, in which Lincoln said, "I do the very best I know how, the very best I can, and I mean to keep doing so until the end. If the end brings me out all right, what is said against me won't amount to anything."

I came into this world when the Civil war was almost contemporary history. It was only twenty years after Appomattox. It was only a matter of forty years following the admission of Iowa to the union. To have passed through the Biblical span of life in Iowa is to have been a witness to many remarkable things. In only one respect, during my lifetime have things remained very much as they were when I was born. That one respect is that the men and women of today are not essentially different from their pioneer grandparents.

Even when I was first elected in 1914 and first became a member of the General Assembly in 1915, the Civil war was almost recent history and the Spanish-American war was only yesterday. There still were serving in the house and senate veterans of the Civil war, such as the gallant George W. Crozier of Marion county, who was one of my colleagues in the house during my first two terms. I remember well the excitement and turmoil of the Thirty-seventh General Assembly when World War I broke out. I also remember better my days in the General Assembly during World War II, and again during the recent Korean conflict. Through all of these periods of warfare, the state of Iowa has remained staunch and steadfast to the traditions of the 
patriots who have represented it upon the fields throughout the history of the State.

But, I prefer to dwell more today upon the accomplishments of the men and women who have served Iowa in times of peace as well as in war, for as a great poet has said, "Peace has its victories no less renowned than war."

The governor of Iowa, when I first took my seat in the House, was a man of vision and outstanding courage, the Honorable George W. Clarke of Dallas county. He had also served in four sessions as a member of the house and two as its speaker. Today his name is not heard so frequent$1 \mathrm{y}$, but our magnificent state grounds are a monument to his memory, for it was the courageous battle which Governor Clarke inaugurated and carried to a conclusion that resulted in our present beautiful capitol grounds. I remember well the controversy which raged over the capitol extension proposal, and the efforts which were made during my first session to halt the project in its infancy. It was bitter battle, but today, who would give up our capitol with its magnificent setting and the buildings which adorn it for a hundred times what it cost in dollars and cents.

I like to remember my earlier sessions because they were marked by some of the bitterest fights over our highway program that have occurred during my entire 42 years of legislative service. We owe much to now forgotten men who had vision and foresight in those earlier days to lay the foundation for a highway system which will never be completed, but which stands as one of the best balanced, including as it does our county, secondary and primary roads, and best serving highway programs anywhere in the nation. I remember, for example, Nicholas Balkema, John W. Foster, Wallace Arney, G. L. Caswell, Justin Doran, Leslie Francis, Clem Kimball, Guy Gillette, Fred L. Maytag, Addison Parker and George Cosson, who were among the leaders in this battle. They were the men who helped to set up what is now our State Highway Commission, envisioned our great primary road system and made other plans for the future, with a foresight that is bearing such fruits today.

I remember such other men as Joe Anderson, Justin Barry, David E. Mackie, Lee W. Elwood, Charles Santee, W. A. Mooty, Herb Dean, James B. Weaver, Henry Brady and Jay Shaff, who were among our house leaders in the early battles for good roads.

I have stated before in public addresses that I consider the Iowa General Assembly to be our greatest training school for statesmen. It is in this hall that a very large number of our governors, congressmen, and United States senators get what I may term their elementary education in statesman- 
ship. The Hon. Burton E. Sweet, to whom you have just listened, a man who is held in highest esteem throughout the state, is one of them.

It has been my privilege to serve as a legislative colleague with all of the governors of Iowa who have served since 1915. I have had the pleasure of serving with a large number of our congressmen and with many who later gained distinction on the district bench and in the supreme court of the state of Iowa.

The battles over highway legislation have been mentioned, and there were other contests in the General Assembly equally momentous, which, in their result, helped make more Iowa history. I remember, for example, such men as S. W. Klaus, Charlie Dutcher, Eli Perkins, Joe Allen, John T. Clarkson, John Hammill, Anthony McColl, Fred Larrabee, Wm. Larrabee, James A. Smith, Ed Cunningham, W. L. Harding and C. B. Murtagh. I mention these men particularly because they were among the leaders of what has proven after 30 years of test to be one of the finest programs of public health education that any state enjoys. These were among the men who were responsible for our Crippled Children's Hospital and for the great Rockefeller University Hospital at Iowa City, and for their part in building up such institutions as our great State University, our State College of Agriculture at Ames, and my own favorite institution, the State Teachers College at Cedar Falls.

It was men of this type also, who helped to establish the policy of adequate care for the unfortunate. I could extend this list indefinitely, of course, but these men come to my mind as typical of the Iowans who rose beyond personal prejudice, beyond all selfish interests, to make Iowa one of the leaders in the field that was new when I was young.

It is natural, of course, that today I should review in my mind the memories of the men with whom I have had the privilege of serving. It is also natural that I am inclined to dwell more upon a generation which is passing from the picture than upon our present-day younger generation. But, before I pass from the present generation of members of the legislature, I want to pay tribute to those of the last few sessions who have approved another very important adjunct to their aid for the unfortunate by starting a new program to bring back to normal life, if possible, the many handicapped and retarded children. This action will bring great praise and commendation in future years.

I do not need to pay tribute to my contemporaries of the last score of years. Their work is well known. They are still active, and they are preserving, as I have said, the traditions of prior years. The time will not be so long 
when no one will recall, other than through the pages of history, some of the men whom I have mentioned. What I am trying to do is to pay tribute to the thousands upon thousands of men and women with whom I have had the privilege of helping in the work to make Iowa a better state in which to live.

We must not lose sight of the fact that Iowa is basically an agricultural state. We must aid in every way possible the agricultural interests, and must insist upon soil conservation so that we may continue to raise upon our farms the necessary food to help feed the world. If we fail to preserve our soil and protect agriculture, the future of our state and the future of our country is in jeopardy.

But, likewise, we are fast becoming an industrial state. Our processing and manufacturing products are now, in dollars and cents, exceeding our agricultural income. We must encourage more industry to come to Iowa. A great percentage of our tax money is spent for education, and rightfully so. It costs the people of Iowa approximately $\$ 9,800$ per pupil from the time the child starts in kindergarten and gets through college. In other words, I am reliably informed that for the period ending June 30, 1955, in one of our higher educational institutions the cost was $\$ 948.72$ per pupil per year. I am also reliably informed that the average cost in high schools per pupil is $\$ 600.00$ per year, and in the elementary grades the cost is $\$ 450.00$ per pupil.

Now, in the past few years, too many of our young graduates whom we have educated, leave the state for greener fields, and we should make a supreme effort, considering our financial investment in these students, to provide satisfactiory employment for them within our own boundaries. I have been informed by one of our large state institutions that practically $78 \%$ of the annual graduates seek employment in other territories outside the state. We must in no way be unfair with the manufacturer who employs thousands of loyal workers who pay individual taxes, in order that our state may continue to exist on a high plane. Both agriculture and industry should be protected at all costs.

I hear a great deal at times of the "good old days" and how they were so much better than those we now enjoy. I am highly skeptical on this point. In fact, I like living in this world today much better than I ever did before. It is a much more comfortable place in which to live. I remember well when such plagues as smallpox, diphtheria and what we called "consumption" in those days were considered almost commonplace.

I can remember, of course, when we had no such things 
as automobiles, radios and television. I was pretty well grown-up before I rode in an automobile, and the telephone was somewhat of a curiosity when I was a lad, along with such things as the electric light. One of my duties as a boy was to gather the lamps, clean and shine the chimneys, fill them with kerosene and trim the wicks so the flame would blaze true, in readiness for the next evening's illumination.

What has happened in Iowa in the last few years relative to the use of electricity? It has been increasing by leaps and bounds, and now we depend so much on the kilowatt that the privately owned utilities of Iowa have, of their own initiative, almost completed a network of high lines and power plants so that it covers practically every community in our great state. In case of an emergency in any community, with the pressing of a button or the flipping of a switch, they can secure power from far away distant places, so that we in Iowa can be practically assured of continuous service for all times in the future. And keep in mind that this was all done with private capital.

I do not believe that people were any less happy in the older days than they are now. They did not miss things they did not have, but the "good old days" really were not as "good" as they were painted. Neither are present times as bad as some are often inclined to think. I am convinced, as I grow somewhat older, that the world and the people in it are getting better. I have always been a great advocate of the theory that people who are able to do so should take care of themselves. I have also, however, in later years arrived at the conclusion that people who are fortunate enough to be able to help others who are less fortunate should put in a great deal of their time and money in doing that very thing.

As I wander through the galleries of the State Historical building and wonder what manner of men they were, whose likenesses are hanging there in their picture frames, who came long before my time, I like to think of them as I hope future visitors will think of me. I would like to be remembered by the people who will gaze at my picture, long after I am forgotten by living men, as a humble citizen of Iowa who did his best to serve his fellow citizens, his state, his nation and his God.

The Waterloo Amvets Chorus of 24 members interspersed the program with three songs.

The Rev. C. J. Gunnell, pastor of Waterloo Christ Episcopal Church in which McFarlane is senior warden, 
offered the invocation. The Rt. Rev. Monsignor E. J. O'Hagan of Waterloo pronounced the benediction.

The event was a notable one with over 400 assembled, and following the presentation program a reception was given in the executive suite of offices, in charge of Mrs. Hoegh, wife of the governor, at which refreshments were served.

\section{Pilgrims \\ By Esther Kem Thomas}

They sowed their grain on rugged unknown soil, That gallant few, And reaped a harvest from their prayer and toilThey sowed faith, too!

They worked for sustenance, they fought for life;

Their numbers grew,

And in their hearts grew thankfulness ... .

And faith, anew!

We have their pilgrimage to carry on,

Rough roads to hew

Toward peace and unity and world-wide dawn-

Faith sees us through...

And when our heritage of hill and plain

We pause to view,

We offer thanks that when they sowed their grain They sowed faith, too!

-from "Gracious Bounty" 
Copyright of Annals of Iowa is the property of State of Iowa, by \& through the State Historical Society of Iowa and its content may not be copied or emailed to multiple sites or posted to a listserv without the copyright holder's express written permission. However, users may print, download, or email articles for individual use. 